\begin{tabular}{c|c|c}
\hline \hline $\begin{array}{c}\text { Vol. 34(3):275-286 } \\
\text { http://dx.doi.org/10.4217/OPR.2012.34.3.275 }\end{array}$ & Ocean and Polar Research & September 2012 \\
\hline \hline
\end{tabular}

\title{
Article
}

\section{기후변화와 개체의 생활사}

\author{
이후승 ${ }^{1,2 *}$ \\ 1사이먼 프레이저 대학교 생물학과 \\ 버나비, 브리티시콜롬비아주, V5A $1 \mathrm{~S} 6$, 캐나다 \\ 2퀘벡대학교 생물학과 \\ 몬트리올, 퀘벡주, $\mathrm{H} 3 \mathrm{C} 3 \mathrm{P} 8$, 캐나다
}

\section{Climate Change and Individual Life History}

\author{
Who-Seung Lee 1,2* $^{1,2}$ \\ ${ }^{1}$ Department of Biology, Simon Fraser University \\ Burnaby, BC V5A 1S6, Canada \\ ${ }^{2}$ Département des Sciences Biologiques, Université du Québec à Montréal \\ Montréal, QC H3C 3P8, Canada
}

\begin{abstract}
Over the last 20 years there have been more than 3000 peer-reviewed papers relating to climate change and biodiversity published, and still the numbers are increasing. However, most studies focused on the impacts of climate change at population or community levels, and the results invariably reveal that there has been, or will be, a negative effect on the structure and pattern of biodiversity. Moreover, the climate change models and statistical analyses used to test the impacts are only newly developed, and the analyses or predictions can often be misled. In this review, I ask why an individual's life history is considered in the study how climate change affects biodiversity, and what ecological factors are impacted by climate change. Using evidence from a range of species, I demonstrate that diverse life history traits, such as early growth rate, migration/foraging behaviour and lifespan, can be shifted by climate change at individual level. Particularly I discuss that the optimal decision under unknown circumstance (climate change) would be the reduction of the ecological fitness at individual level, and hence, a shift in the balance of the ecosystem could be affected without having a critical impact on any one species. To conclude, I summarize the links between climate changes, ecological decision in life history, the revised consequence at individual level, and discuss how the finely-balanced relationship affects biodiversity and population structure.
\end{abstract}

Key words : climate change, compensatory growth, life history, optimal decision, individual, population

\section{1. 기후변화가 생물다양성에 미치는 영향}

기후변화 현상은 직접 또는 간접적으로 생물의 다양한 특성(번식, 성장, 이동, 면역, 분포 등)에 영향을 미친다 (Fleming and Candau 1998; Walther et al. 2002; Parmesan

*Corresponding author. E-mail : whoseung@gmail.com
2006). 생물은 그들이 서식하는 환경과 생태적 지위에서 최적의 생태적 적응도를 선택하여 안정적인 균형을 유지 하도록 진화되었다. 또한 생물은 서식(또는 번식) 환경에 대한 과거의 경험과 유전 정보에 의한 전략 그리고 최적 행동의 선택을 통해 그 균형을 유지한다(Roff 2002). 따 라서 기후변화의 영향으로 불규칙적이면서 기존과 다른 온도 등 환경 변화는 생태적 스트레스를 증가시키고 
(Heidkamp 2010), 안정된 균형과 적응-선택의 과정을 방 해하며, 동시에 바뀐 환경에 생물이 적응하기 위해 새로운 균형과 선택에 부가적인 시간과 에너지를 투자하게 한다.

생태계 복잡성 정도는 생물다양성 평가를 통해 설명될 수 있다(Sala et al. 1999). 예를 들어, 서식지의 환경상태 에 영향을 받는 생물다양성의 크기는 서식지 안에 얼마나 많은 생물들이 안정된 관계를 유지하며 서식하고 있는지 를 평가할 수 있는 기초가 되며, 이를 통해 서식환경이 개 선되었는지 또는 파괴되었는지를 알 수 있다(Hillebrand and Matthiessen 2009). 또한 환경에 대한 생물의 반응은 유전자, 개체, 종, 군집 및 생태계 수준으로 구분되어 평가 되는데(Agapow et al. 2004), 생물다양성은 종내, 종간 그 리고 생물과 환경과의 관계 등 다양한 조건에서의 분석을 통해 평가 및 예측된다. 따라서 기후변화와 생물다양성 의 관계는 대부분 종 생태적 관계를 분석하는데 집중되 고 있다.

기후변화 연구에 있어서 개체군 내의 생물다양성 변화 에 대한 연구는 최근 20 년간 꾸준히 증가하고 있다(Fig. 1). 대부분의 연구는 장기적인 온도변화 모니터링과 기후 변화 시나리오를 이용하여 기후변화에 따른 생물 종의 분 포와 분산(또는 이주) 그리고 개체군이나 군집의 성장과 구조의 변화를 분석하는 연구 등이 주로 진행되었다(예, O'Neill et al. 2008; Boden et al. 2010; Westerling et al. 2011; Clark et al. 2012). 본 연구에서는 우선 기후변화가 생물다양성에 미치는 영향에 대한 연구 동향을 알아보기 위해 논문 검색 데이터베이스 Web of Science(http://www. webofknowledge.com)에서 키워드 검색을 통해 분석하였 다(Fig. 1). 키워드 검색은 2012년 1월 31일까지 Web of Science에 등록된 자료를 이용하였다. 'Climate change AND biodiversity'를 키워드로 하여 조사한 논문의 수는 1991년부터 2011년까지 총 3,211편이었다. 흥미롭게도 1991년에 6편이었던 논문이 2006년 이후부터 급격히 증 가하여 2011년에만 667편이 출판되어 100배 이상 증가 되었는데, 2005 년도에 결성된 $\mathrm{G} 8$ 기후변화 원탁회의 (Climate Change Roundtable)를 통해 학계와 산업계 등 여러 분야에서 기후변화 연구에 대한 투자와 관심이 높아 진 결과에 따른 것이라 판단된다.

기후변화가 생물다양성에 미치는 영향에 대한 연구는 대부분 개체군이나 군집의 구조와 성장 그리고 이동 경향 등에 관하여 수행되었는데, 키워드로 검색한 결과 전체 3,211 편의 논문 중 868 편으로 $27 \%$ 의 비중을 차지하고 있 었다(key word = 'climate change AND biodiversity AND community'). 최근 기후변화와 생물다양성의 영향에 대한 연구에서 생태적인 분석과 예측의 정확도를 높이기 위해 분석을 개체 수준에서 시도하는 방법이 제시되고 있다 (Clark et al. 2012). 공교롭게도 'climate change AND

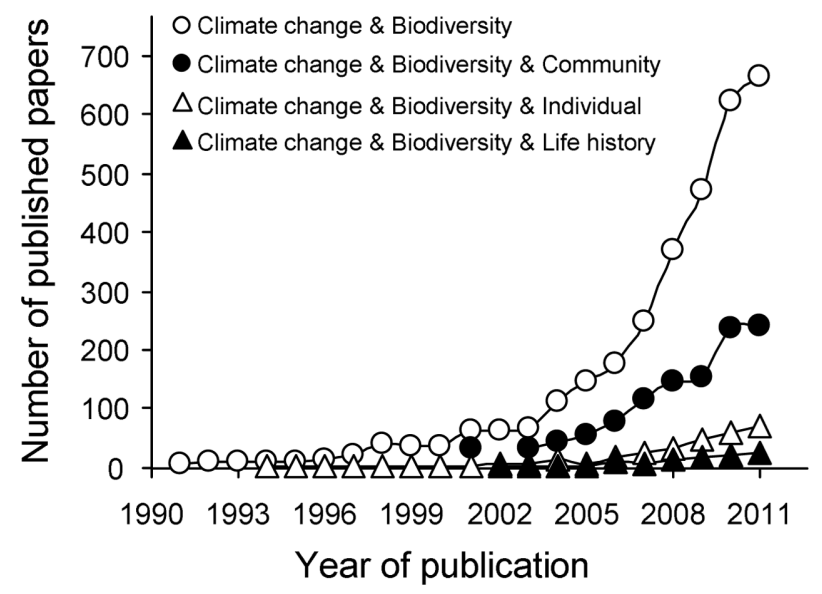

Fig. 1. Growth in the research about effects of climatechange on biodiversity, based on a keyword search of articles using 'climate change AND biodiversity' (open circle), 'climate change AND biodiversity AND community' (closed circle), 'climate change AND biodiversity AND individual' (open triangle), and 'climate change AND biodiversity AND life history' (closed triangle) on the Web of Sciences carried out in 31 January 2012. Web of Science URL: http://www. webofknowledge.com

biodiversity AND individual'을 키워드로 검색된 논문 수 는 총 303편이었으며, 2008년 이후부터 급격히 증가하고 있다(Fig. 1). 그러나 아직까지는 주로 장기간의 연구와 메 타분석방법을 이용한 온도 변화에 따른 개체의 생태적 결 과를 분석하여, 생물다양성의 구조와 분산 형태 그리고 기 후변화의 관계를 더욱 긴밀하게 이해함을 목적으로 하고 있다. 예를 들어, Parmesan and Yohe (2003)은 1,700여종 이상의 식물을 대상으로 서식하는 고도와 위도 그리고 온 도에 대한 식물의 특이성 연구에서 전 지구적 메타분석방 법을 이용하여 기후 온난화에 따른 종의 분포 현상이 바 뀌고 있음을 보고하였다. 최근 과거 개체군이나 군집 단위 에서 수행된 기후변화의 영향에 대한 예측의 정확도가 감 소함에 따라, 많은 생태학자들은 섭씨 $2-5^{\circ} \mathrm{C}$ 정도의 온도 변화만으로 과연 생물다양성에 변화가 있을지에 대해 의 문을 가지기 시작했다(Parmesan and Yohe 2003; Karl et al. 2009). 특히 예측의 정확도를 높이기 위해 Clark et al. (2012)은 기후변화 연구에 개체의 생태적 영향을 포함한 분석의 필요성을 주장하였으며, Urban et al. (2012)는 수 학적 모델을 통해 기후변화에 의한 종 멸종의 속도가 개 체 수준에서의 종간 경쟁과 종간 분포 변이를 분석에 포 함시켰을 때 빠르게 증가함을 증명하였다. 개체군이나 군 집 단위에서는 종종 작은 온도 변화에 따른 다양성의 구 조변화가 명확하게 나타나지는 않는다. 그렇지만, 반대로 개체는 작은 온도 변화에도 생리적으로 민감하게 반응하 
기 때문에, 최근 기후변화와 생물다양성 연구에 개체의 생 활사를 포함하여 분석하는 연구가 꾸준히 증가하고 있다 (Fig. 1): Web of Science DB에서 'climate change AND biodiversity AND life history' 키워드로 검색한 결과, 2002년도에 2편의 논문이 처음 발표되었고, 2011년까지 102 편 $(3.2 \%=102 / 3211$ 편 $)$ 이 발표되었다.

본 종설에서는 개체의 성장, 번식 그리고 이동과 같은 생활사 특징과 결과에 근거한 분석이 기후변화 연구에 어 떠한 이점을 가지는지를 최근 연구 동향 분석을 통해 고 찰하려고 한다. 특히, 온도와 먹이 같은 환경 변화에 대한 개체의 전략적 선택과정인 보상성장(compensatory growth) 기작을 통해 환경 변화에 따른 개체 생활사의 상충관계 (life-history trade-off) 그리고 스트레스 역학이 기후변화 연구에 어떻게 적용될 수 있는지를 고찰하고자 한다.

\section{2. 기후변화와 개체의 생활사}

생물의 생활사는 서식 환경과 종내 혹은 종간의 관계에 민감하게 반응한다(Stearns 1989; Roff 2002). 바다의 표 층수온(Sea-Surface Temperature, SST)은 괭이갈매기 (Larus crassirostris)의 산란시기를 결정하는 중요한 환경 요인 중 하나로 알려져 있으며(Tomita et al. 2009), 북극 산 참솟깃오리(Somateria mollissima)는 얼음이 녹는 시기 에 맞추어 새끼들의 부화가 시작되도록 전략적으로 번식 과 산란시기를 조절한다(Love et al. 2010). 이와같은 환경 과 생물과의 관계는 성장과 번식 그리고 수명과 같은 개 체 생활사 적응도를 극대화하기 위한 최적 선택과정으로 표현할 수 있다(Roff 2002). 바다의 표층수온에 대한 정보 는 이전 번식 경험과 본능, 즉 유전자 속에 내재된 정보를 통해 어느 시기에 $(=$ 먹이자원인 어류가 번식지 주변에 가 장 많이 도래하는 바다의 표층 수온이 되었을 때) 산란을 하는 것이 번식 성공률을 가장 높일 수 있는지를 판단하 여 최적 산란일을 결정하는 근거가 된다(Tomita et al. 2009). 또한 북미산 도요(Calidris mauri)와 같이 장거리를 이동(또는 회유)하는 종은 바람의 방향과 세기, 그리고 온 도와 같은 현재의 환경 상태와 과거의 경험을 바탕으로 이동하는 동안 가장 적은 에너지로 생존 가능성을 극대화 할 수 있고, 원하는 시기에 도착할 수 있는 최적 출발 시 기를 결정한다(Clark and Butler 1999). 이와 같이 자연 선택은 생물이 주어진 환경에 잘 적응하고 생존할 수 있 는 최적 조건을 선택하도록 진화되어 왔다. 기후변화는 이렇게 선택된 최적 조건에 영향을 주어 궁극적으로 생 물의 생존과 번식에 영향을 주게 될 것이다. 예를 들어, Dickey et al. (2008)는 북극에서 번식하는 흰기러기 (Chen caerulescens)에 대한 16년간의 번식 자료 분석을 통해, 봄철 기온 상승이 둥지 밀도를 증가시키고 첫 산란
일을 앞당겼으며, 번식 밀도의 증가는 둥지 장소 선택과 섭식 행동의 경쟁을 높여 결과적으로 번식 성공률이 낮아 졌음을 보고하였다. 특히 16 년 동안 번식 개체군의 번식 성공률이 약 $\pm 50 \%$ 의 변이를 보였는데, 높은 변이의 이유 가 봄철 기온 상승으로 인한 개체의 둥지 장소 선택 시기 의 불일치에 따른 결과인 것으로 고찰하였다.

생활사 연구는 생태적 과정의 결과와 환경과의 관계를 분석하는데 목적이 있다(Roff 2002). 환경 변화가 번식 수 행에 어떻게 그리고 어떠한 영향을 주는지, 예를 들어 환 경 상태에 따른 산모의 건강(또는 영양) 상태가 새끼의 발 달과 성장 그리고 생존에 어떠한 영향을 줄 것인지를 환 경 상태와의 상충관계를 통해 분석함으로써 최적의 전략 적 선택이 무엇인지를 알아보는 것이다. 다시 말해, 개체 의 '발생-성장-번식-노화'와 같은 전형적인 생활사 연구는 보편적으로 환경 변화에 대한 개체의 생활사 전략이 어떤 과정과 선택에 의해 진화 및 적응되어 가는지를 분석하는 데 목적을 두고 있다(Roff 2002). 반면, 군집(또는 개체군) 수준에서의 연구는 군집의 크기와 구성은 어떠한지 분석 하고, 환경 변화에 따른 군집의 유동성이 어떻게 바뀐 환 경에 적응 되어 가는지를 예측함을 목적으로 하고 있다. 따라서 접근하는 주제는 다소 차이가 있음에도 불구하고, 생물 시스템 구조상 각각의 연구 과정은 서로 밀접한 관계 가 있기 때문에, 기후변화와 생물다양성에 대한 연구는 군 집이나 개체 수준에서 수행하는 상이한 연구 방법과 목적 을 서로 보완하며 진행할 필요가 있음이 최근 주장되고 있다(예, Clark et al. 2012).

기후변화로 인한 환경변화가 개체의 성장, 번식 그리고 노화에 직접 영향을 줄 수 있으므로 변화된 새로운 환경에 적응하여 번성하기 위해 개체는 생활사 전략을 빠르게 수 정한다(Roff 2002). 따라서 개체 수준에서의 연구는 이러 한 전략적 수정이 개체의 선택과 행동에 영향을 주었는지 그리고 그 선택의 결과로 번식과 생존이 증가 또는 감소되 었는지를 분석한다. 반면, 개체군이나 군집 수준에서는 개 체의 최적 선택에 따른 번식과 생존의 결과를 가지고 개체 군이나 군집의 성장 결과를 비교 설명한다. 마찬가지로 기 후변화에 의한 생물다양성은 주어진 환경에 대한 최적 선 택의 결과로서 새로운 환경에 대한 적응 여부를 판단하는 근거가 될 수 있는데, 바뀐 환경에 적응한 종들의 빈도 상 승은 다양성의 증가를, 반대로 적응하지 못하고 다른 곳으 로 이동하거나 절멸한 종의 증가는 다양성의 감소를 야기 할 것이다. 다시 말해서 개체군이나 군집 수준에서의 생태 적 결과는 결국 개체 수준의 다양한 생활사적 결과가 모여 진 하나의 경향으로 설명될 수 있다(Grimm and Railsback 2005). 따라서 개체의 생활사는 많은 생태적 과정에 따른 경험과 정보에 의해 주어진 환경에서의 최적 선택에 의해 결정되며, 이것을 포함한 군집이나 개체군 수준에서의 다 
양성 구조와 분산 형태의 변화분석은 기후변화의 영향을 보다 생태적이고 정확하게 획득할 수 있기 때문에 이와 같 은 접근법에 대한 충분한 논의가 필요하다.

\section{3. 기후변화와 상충관계}

생물은 언제나 적응도를 극대화하기 위해 최적의 전략 과 선택을 추구하며, 그 선택은 서식지 환경과의 상충관계 를 통해 결정될 수 있다(Roff 2002). 상충관계는 개체의 생활사 전략 선택의 ‘규칙’이다(Charnov 1997; Roff 2002). 왜냐하면, 먹이와 서식지 같이 생물이 이용할 수 있는 자 원은 언제나 유한하므로 주어진 상황에서 상충관계를 통 해 유한의 자원을 성장과 번식 등에 최적화된 전략으로 분배해야 하기 때문이다. 기후변화는 바로 이 상충관계에 의한 최적 선택의 과정을 방해하여, 개체의 변경된 최적 선택 전략 또는 감소된 적응도가 개체군이나 군집 구조의 변화를 유도했을 것이다. 특히 기후변화에 따른 서식지의 온도 변화는 직접적으로 개체의 상충관계에 영향을 줄 수 있다. 예를 들어, 연어(Salmo salar)는 강이나 하천에 서 1-2년간 충분히 성장한 다음, 바다로 회유한다. 성장 기간 동안 서식지의 수온 상승은 연어의 신진대사를 증가 시켜 성장 속도의 감소를 초래한다(Groot and Margolis 1991). 일반적으로 어류는 온도가 상승하면 성장 속도가 빨라지지만, 임계온도 이상 높아지면 신진대사량의 상승 으로 인하여 성장 속도는 오히려 감소한다(Bone and Moore 2008). 그러나 연어는 다른 어류에 비해 상대적으 로 임계온도가 낮기 때문에, 수온의 작은 상승만으로 신진
대사량은 높아지고, 성장속도는 느려지게 된다. 이로 인해 바다로 회유할 시기까지 회유를 위한 충분한 발육을 하지 못하게 된다. 이와같이 미 발육된 어류는 최적 회유시기를 놓치게 되고, 결국 이들 미 발육 어류의 생존율이나 회유 성공률이 감소하게 된다(Marschall et al. 2011). 대부분의 회유성 동물은 환경 조건(예, 바람 세기와 방향 그리고 온 도 등)과 몸 상태를 과거의 경험과 유전적 정보 $(=$ 본능 $)$ 에 근거하여 최적 회유시기를 선택한다. 다시 말해, 회유 성 공률을 높이기 위해 회유시 소모되는 생태·생리적 에너 지를 절감할 수 있는 최적 회유시기를 상충관계에 의해 결정하며, 이 때 과거의 경험과 유전적 정보가 결정에 영 향을 주는 것이다. 그러나 기상이변과 같은 예측 불가능한 환경 변화는 잘못된 상충관계의 선택을 유도하여 생태적 적응도를 감소시킬 수 있다. 이처럼 성장과 번식 그리고 이동과 같은 개체 생활사에서의 최적 선택은 기후변화에 의해 번식실패나 높은 사망률을 야기하여 개체군이나 군 집 크기를 감소시키는 등 치명적인 영향을 줄 수 있다. 예를 들어, 섬에 집단으로 번식하는 재갈매기(Larus argentatus)는 산란일과 부화시기를 번식지 주변에 산란하 는 열빙어(Mallotus villosus)의 도래시기와 일치하도록 전 략적으로 번식시기를 결정한다. 그러나 갑작스런 기온의 하강은 온도에 민감한 열빙어의 도래 시기를 늦추었지만, 과거의 경험에 의해 부화시기를 결정한 재갈매기의 새끼 들은 부화 시기와 열빙어도래 시기의 불일치로 인하여 새 끼 사망률을 증가시켰다(Rodway and Regehr 1999). 생물 은 오랜 시간 동안 반복되는 경험을 통해 최적조건을 선 택(예, 열빙어 도래 시기와 일치되는)하도록 진화해 왔다. (a)

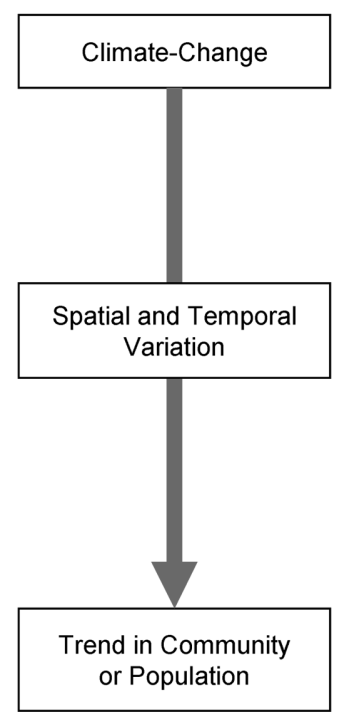

(b)

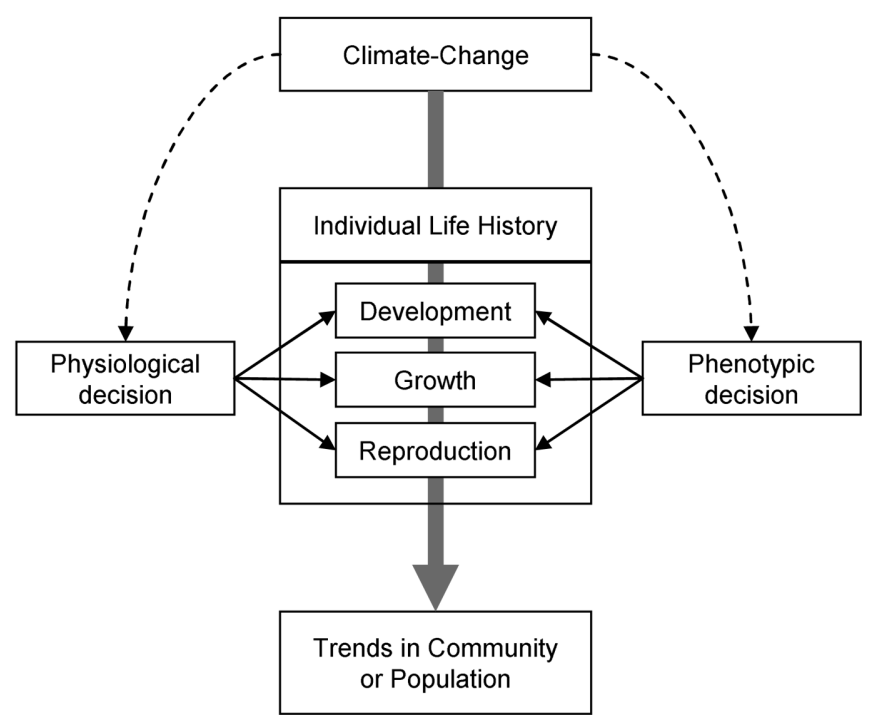

Fig. 2. (a) General analysis pathway to investigate impacts of climate change on trend in community or population (or biodiversity). (b) The scheme of links between climate change, individual life history and trends in community: direct (solid line) and indirect (dashed line) effects. See text more detail 
하지만 예상치 못한 환경 변화(예, 기온 하강 또는 상승) 는 최적조건을 더 이상 최적이 아닌 조건으로 바꿈으로서 생물의 번식 실패 등을 통해 멸종까지 이르게 할 수 있을 것이다.

지금까지의 기후변화와 생물다양성에 대한 연구는 대부 분 직접적으로 기후변화에 의한 다양성의 구조와 분산형 태 변화 분석을 통해 수행되었다(Fig. 2a). 그러나 앞서 언 급했듯이 기후 변화와 개체의 상충관계에 따른 최적 선택 에 의한 접근 방법이 분석과 예측의 정확성과 정밀성을 높일 수 있다는 결과가 보고되고 있으며, 그 이유가 생태 적 시스템을 기초로 하기 때문인 것으로 알려져 있다 (Urban et al. 2012). 다시 말해 Fig. 2b에서와 같이 기후변 화는 생리적 선택과 형태적(또는 표현형의) 선택에 따른 전략적 생활사 상충관계에 영향을 주어 개체군이나 군집 구조의 결정에 영향을 줄 수 있다. 왜냐하면, 첫 번째로 기 후변화에 의한 온도 변화는 포식행동과 성장 속도에 영향 을 줄 수 있기 때문이다(Le Lann et al. 2011; Lee et al. 2011). 생리적으로 온혈동물(예, 포유류, 조류 등)과 달리 냉혈동물(예, 어류, 양서파충류, 곤충 등)은 온도 변화에 민감하게 반응한다. 예를 들어, 온도 상승에 의한 신진대 사량의 증가는 채내 산소 요구량과 에너지 소비량의 증가 를 유도하며, 동시에 체내의 세포 손상(cellular damage)을 증가시켜 생물의 성장속도를 감소시킨다(Ferguson et al. 2008; Lalouette et al. 2011). 이 때 증가된 세포 손상, 즉 산화스트레스는 세포분열과 세포성장의 기작을 방해하고 또한 체내 호르몬 균형을 깨뜨려 번식과 수명을 감소시키 는 원인이 된다(Frisard et al. 2007; Garratt et al. 2011). 따라서 기후변화는 최적화된 생활사 전략(즉, 최적의 성장 속도를 유지하면서 동시에 스트레스를 최소화하는 전략) 에 의한 최적선택을 어렵게 할 것이고, 결과적으로 성장과 노화의 속도 그리고 번식실패를 증가시켜 개체수와 다양 성의 감소를 초래하게 될 것이다. 두 번째로 기후변화와 같은 환경변화는 생물의 형태적 유연성(표현형의 유연성) 을 높일 수 있기 때문이다(Pigliucci 2001). 환경 변화에 의한 생물 표현형의 변화 정도(반응양태)는 환경변화(환경 구배)의 정도가 클수록, 다시 말해 온도나 강수의 시공간 적인 변화가 커지면 증가한다(Schlichting and Pigliucci 1998). 예를 들어, 큰 가시고기(Gasterosteus aculeatus)는 일반적인 골격과 피부사이에 뼈와 비슷한 경골성의 인판 (또는 경판, Armor plate)이 존재한다. 이것은 포식자로부 터 몸을 보호하기 위해 발달된 것으로(Bell and Foster 1994), 가시고기의 서식지가 해수일 경우 인판이 몸 전체 를 뒤덮을 만큼 발달되어 있지만, 내륙서식지 즉 담수에서 서식하는 가시고기는 인판의 수가 적거나 인판이 발달되 지 않는다. 왜냐하면 담수에서는 바다보다 포식자 수가 상 대적으로 적기 때문에 전략적으로 인판을 퇴화시키고 대
신 성장 속도를 빠르게 하여 먹이 경쟁에서 유리하도록 진화하였기 때문이다(Leinonen et al. 2011). 가시고기는 배아발달(embryo development) 시기에 이미 유전형에 의 해 인판의 개수가 결정되지만, 서식지의 수질 환경 $(=$ 염분 의 비율\%)에 적응하기 위해 인판의 개수, 즉 표현형을 변 경하는 것이다(Marchinko and Schluter 2007). Stott et al. (2008)은 기후변화(=온도상승)가 해수와 담수의 염분농도 를 빠르게 증가시킬 수 있으며, 이러한 염분스트레스의 증 가는 수생생물의 성장률과 번식 성공률을 감소시킬 수 있 음을 보고하였다. 따라서 Fig. $2 \mathrm{~b}$ 에서의 형태적 선택은 기후변화에 의해 바뀐 환경 조건이 새로운 환경에 적응 (=생존 기회의 상승)하기 위한 표현형을 유도하였고, 이러 한 표현형의 변이는 번식수행에도 영향을 주어(예, 큰 가 시고기 표현형의 차이에 따른 생식적 격리, Kitano et al. 2009 ) 결국 생물의 다양성을 감소시키는데 영향을 줄 수 있을 것이다. 세 번째로 기후변화는 직접적으로 개체의 다 양한 전략적 선택(예, 행동범위, 포식행동)에 영향을 줄 수 있기 때문이다. 온도의 상승은 신진대사의 변화로 포식과 피식과 같은 취식행동의 형태와 속도를 조절한다(Arbuthnott and Brigham 2007). 예를 들어, 기후변화에 의한 수온의 상승은 어린 무지개송어(Oncorhynchus mykiss)의 신진대 사와 섭식활동을 증가시켰지만, 임계온도 이상 높아진 수 온은 성장속도를 감소시켜, 높아진 섭식활동으로 포식자 들에게 노출될 확률이 증가되어 수온이 낮았던 시기보다 생존율이 $50 \%$ 감소하였다(Biro et al. 2007).

\section{4. 기후변화와 보상성장}

보상성장은 환경 변화에 대한 생물의 진화적 대응 전략 으로 잘 알려져 있다(Metcalfe and Monaghan 2001; Mangel and Munch 2005; Dmitriew 2011). 초기 발달 단 계의 개체는 극한 환경(먹이 제한, 수온 변동)하에서 성장 이 멈추거나 느려지게 되지만, 이러한 상황이 정상으로 회 복되면 성장은 훨씬 더 가속되어 정상 환경 하에서 성장 한 개체들의 크기(또는 무게)와 곧 같아지게 되는데, 이러 한 기작을 보상성장(또는 catch-up 성장)이라고 한다 (Metcalfe and Monaghan 2001; Dmitriew 2011). 개체의 크기와 생활사와의 관계에 대해서는 아직 많은 토론이 이 어지고 있지만(Reznick et al. 2000), 일반적으로 크기가 크면 경쟁, 번식 그리고 생존에 많은 이점을 가진다(Cote and Hunte 1989). 따라서 열악한 상황(=성장의 감소 또는 멈춤)에 의해 크기가 작아진 개체들은 환경이 정상적인 상황으로 회복 되었을 때 최대한 빨리 크기를 키우기 위 해, 이용 가능한 모든 자원(예, 먹이)을 성장을 위한 에너 지로 사용한다(Ali et al. 2003). 뿐만 아니라, Metcalfe and Monaghan (2003)은 보상성장이 전략적으로 성장을 
빠르게 하여 가장 가까운 시기, 즉 겨울철의 생존을 높이 기 위해 크기를 키우는데 모든 에너지를 사용하며, 이 때 발생하는 생태적 비용(예, 세포 손상)은 성장 과정 이후의 번식이나 수명을 감소시킬 것이라 제안하였다. 보통 동물 의 새끼들은 크기가 클수록 겨울철 생존율이 증가할 뿐만 아니라, 먹이 경쟁에서도 유리하며, 동시에 포식압도 감소 한다(Bone and Moore 2008). 더욱이 번식 초기의 수컷과 암컷의 크기는 배우자 선택 성공률과 산란율 그리고 번식 성공률과도 관련이 있다(Cote and Hunte 1989). 따라서 보상성장에 의해 성장이 빨라지는 것은 예상치 못했던 환 경 변화(예, 기후변화)에 전략적으로 대응하기 위한, 즉 현 재의 생존과 번식 기회 확률을 높이기 위해, 미래의 생활 사 결과와의 상충관계를 통해 유한의 자원을 성장에 집중 적으로 사용하는 것이다. 최근 Lee et al. (2011)는 동적상태-의존 모델링(dynamic-state-dependent modelling)을 이용한 '온도-성장-세포내 손상(temperature-growth-damage)' 모델을 개발하고 보상성장과 생활사 결과의 상충관계 과 정을 고찰하였는데, 보상성장에 의해 누적된 세포내 손상 (또는 스트레스)이 유한한 자원의 최적분배전략에 영향을 주어 보상기간(=빨라진 성장기간) 동안 번식세포의 성장 (=번식투자)보다는 체세포의 성장에 더 많은 에너지를 투 자하여, 결과적으로 번식결과를 감소시켰음을 보였다.

보상성장 연구는 대부분 먹이 자원에 의한 성장 가속과 그에 따른 운동 능력과 번식 그리고 노화속도에 대해서 수행되었다(Álvarez and Metcalfe 2005; Lee et al. 2012). 그러나 어류나 파충류와 같은 냉혈동물은 먹이뿐 만 아니 라, 온도가 성장에 직접적인 영향을 줄 수 있기 때문에 온 도 변화에 의한 보상성장의 연구를 포함해 함께 증가하고 있다: 1990년 11편의 논문이 출판되었으나, 2011년 130편 의 논문이 출판되어 10 배 이상 증가되었다(Web of Science, key word='compensatory growth', 2012년 1월 18일 현재). 온도에 의한 보상성장의 영향은 개체 수준에서의 기후변 화의 영향에 대한 연구와 밀접한 관련이 있음에도 불구하 고 고온 보다는 저온에서의 성장 변화에 대한 연구가 주 로 수행되었다. Nicieza and Metcalfe (1997)는 어린 대서 양연어(Salmo salar)를 이용한 실험에서 수온을 하강시켜 보상성장이 나타남을 실험적으로 보였다. 흥미롭게도 Lee et al. $(2010,2012)$ 는 어린 큰 가시고기를 이용한 온도처 리 실험에서 보상성장(저온 처리)과 함께 역보상성장 ('negative' compensatory growth) (고온 처리)이 진행됨을 처음으로 확인하였다(Appendix 1, Fig. A1a). 특히 성장이 빨라진 것에 의한 보상성장은 번식과 운동 능력을 저하시 켰지만, 성장이 늦어지는 것에 의한 역보상성장은 반대로 향상시켰다. 뿐만 아니라, 수명에도 동일한 형태의 결과를 보임으로(Lee et al. Unpublished data), 온도에 의한 어린 시기의 성장 속도와 형태의 변화가 생활사 전체에 영향을
주고 있음을 알 수 있다(Appendix 1, Fig. A1b).

개체, 군집 그리고 개체군에서의 온도 변화에 의한 성 장과 번식의 영향에 대해서는 이미 많은 연구가 진행되었 지만, 기후변화와 보상성장과의 관계에 대해서는 아직 알 려지지 않았다. 하지만 보상성장을 유도할 수 있는 환경 요인들이 기후변화의 영향을 직간접적으로 받을 수 있기 때문에, 기후변화에 의한 보상성장과의 상충관계가 아마 도 생물다양성의 구조에 영향을 줄 수 있을 것이다. Floder et al. (2010)는 플랑크톤 군집이 염분스트레스에 의해 보상성장이 진행되었으며, 그 영향으로 군집 구성과 다양성에 음의 영향을 주었음을 보였다. 특히 보상성장은 생식세포의 에너지 대사나 성장을 늦추거나 번식기능의 조기노화를 유도하여 번식성공률을 낮추는 것으로 보고되 고 있다. 따라서 개체군의 출생률을 낮추어 생물의 다양성 을 낮추는 결과를 유도할 수 있을 것이다. 그러나 기후변 화에 의한 보상성장과 그에 따른 영향이 생물다양성의 크 기와 구조에 어떻게 영향을 주는가에 대해서는 후속 연구 가 추가적으로 진행되어야 한다.

최근 연구 결과에 의하면 보상성장은 노화 속도를 촉진 시킬 수 있으며, 더욱이 수명이 긴 동물보다 수명이 짧을 수록 그 영향이 더욱 증가한다(Inness and Metcalfe 2008; Geiger et al. 2012). 개체의 노화 속도는 개체군이나 군집 의 개체수통계, 즉 다양성의 구조에 영향을 줄 수 있다. 예 를 들어, 최근 Geiger et al. (2012)는 어린 야생 킹펭귄 (Aptenodytes patagonicus)에서 보상성장이 텔로미어 길이 를 빠른 속도로 짧아지게 하는 요인임을 밝혔다. 텔로미어 는 염색체 말단에 위치하는 DNA 조각으로 세포분열이 일어나는 동안에 길이가 감소하며, 수명과 텔로미어의 길 이가 서로 긴밀한 상관관계에 있음이 최근 많은 연구를 통해 밝혀지고 있다(Haussmann and Mauck 2008). 따라 서 보상성장에 의한 텔로미어 길이의 빠른 단축은 노화속 도의 증가를 야기할 수 있으며, 이것은 개체군의 사망률 증가와 더불어 결과적으로 다양성을 감소시키는 결과를 초래할 수 있을 것이다. 즉, 연령별 개체 수의 구조가 진화 적 안정을 이룬 개체군이나 군집에서 기후변화에 의해 성 장이 빨라지게 되면 수명의 단축을 유도할 수 있고, 또한 운동능력과 번식의 노화 속도를 증가시켜 새로운 개체군 구조로의 진화를 야기할 것이다. 따라서 노화와 수명에 대 한 성장속도의 음의 영향은 기후변화에 의한 다양성의 변 화가 단기간에 끝나는 것이 아니라, 생태적 안정화가 된 이후에도 일정기간 또는 장기적으로 영향을 주는 이유를 설명해 줄 수 있을 것이다.

\section{5. 기후변화와 스트레스}

노화와 성장 그리고 번식에 대한 연구는 생태학뿐 만 
아니라 의학 및 영양학 등 다양한 분야에서 수행되고 있 다. 특히 먹이와 서식지 같은 환경 요인과 경쟁과 협력 같 은 사회적 요인에 의한 스트레스 상승여부와 각 요인들 간의 상호관계를 분석하고, 생물의 생태적 적응도를 극대 화하기 위한 스트레스 최소화 전략과 행동을 분석하는 연 구가 증가하고 있다. 생태적 생활사 연구에서 스트레스의 평가는 일반적으로 코스티코스테론(Corticosterone 또는 CORT), 신진대사량 그리고 산화스트레스등의 변화를 통 해 분석한다(Monaghan et al. 2009; Metcalfe and AlonsoAlvarez 2010; Costantini et al. 2010). 스트레스의 상승은 1 차 적으로 환경 변화와 같은 외적 요인에 의해 영향을 받 지만, 스트레스 요소 간의 상호 작용에 따른 2 차적인 추가 상승도 야기할 수 있다. 예를 들어, 온도 상승에 따른 빠른 성장속도는 신진대사량과 산화스트레스량을 각각 상승시 킨다. 뿐 만 아니라, 높아진 신진대사량은 산화스트레스를 촉진시킨다(Ferguson et al. 2008). 이러한 스트레스 상승 의 상호촉진관계는 어떻게 보상성장과 같은 빠른 성장이 스트레스 누적을 가속시키는 이유를 설명해 준다(Pike et al. 2007; De Block and Stoks 2008). 또한 스트레스 누적 속도의 증가는 기후변화에 의한 작은 온도 차이가 어떻게 생물다양성의 구조에 영향을 줄 수 있는지를 설명할 수 있을 것이다. 왜냐하면 체내의 스트레스 양에 따라 성장속 도와 개체수(번식과 수명에 의해 영향을 받는) 그리고 생 활사 전략이 달라질 수 있기 때문이다. 예를 들어, 나그네 알바트로스(Diomedea exulans)의 섭식 비행은 코스티코 스테론을 증가시키는데, 포식 비행 전 체내의 코스티코스 테론이 높으면 섭식 빈도와 비행 거리를 짧게 하는 전략 (적은 먹이양에 따른 성장률 감소 유도)을 선택하고, 반대 로 코스티코스테론이 낮으면 장거리의 섭식 비행과 동시 에 섭식 빈도를 높이는 전략(많은 먹이양에 따른 성장률 증가 유도)을 선택한다(Angelier et al. 2007).

기후변화에 따른 불규칙적인 온도 변화 또는 온난화는 어류와 양서파충류 같은 냉혈동물의 스트레스를 직접적으 로 증가시킬 수 있다. 우선, 온도의 상승은 명백하게 냉혈 동물의 신진대사량을 높이고 포식이나 번식 등을 위한 활 동성을 감소시킨다(Bone and Moore 2008). 줄무늬웃는개 구리(Limnodynastes peroneii)는 온도가 일정하게 유지되 었을 때보다, 온도 변화의 차이(일일 최대-최저 기온의 차 이)가 클수록 신진대사량과 스트레스가 증가하고 운동 능 력이 감소하는데(Niehaus et al. 2011), 이는 섭식활동뿐 만 아니라, 성장 속도의 감소와 포식압의 증가를 유도한 다. 또한 온도 상승은 해양의 플랑크톤이나 녹조류의 성장 을 빠르게 하여, 어류나 다른 수생 생물의 산소 결핍을 유 도하여 성장을 느리게 하거나 생존율 감소를 야기한다. 즉 온도 상승에 따른 플랑크톤과 녹조류의 개체 수 증가는 수중의 용존 산소량을 감소시켜, 어류의 저산소증을 유발
하고 신진대사량을 높인다(Kalkstein 1993). 뿐만 아니라, 시각적인 방해를 통해 섭식비용(예, 먹이를 찾는데 소비되 는 에너지)을 늘리고, 종 내의 먹이 경쟁 상승과 포식자에 게 노출될 확률을 높이며, 나아가 포식자의 피식자를 찾기 위한 에너지 소비를 증가 시킨다(Kalkstein 1993). 이러한 포식자-피식자 그리고 먹이 경쟁의 관계 변화는 또한 코 스티코스테론의 증가를 유도한다(Clinchy et al. 2011). 예를 들어, 갈라파고스 바다이구아나(Amblyrhynchus cristatus)는 새로운 포식자가 나타나거나 동종의 개체수가 증가하여 먹이경쟁이 높아지면, 코스티코스테론이 증가하고 포식 빈도와 행동이 급격히 감소한다(Rodl et al. 2007). 한편, 온도 상승(단, 임계온도보다 낮은)은 어류의 가속 성장을 야기하여 신진대사량과 스트레스를 증가시킬 수 있다. LeBlanc et al. (2011)는 어린 무지개 송어를 높은 수온에 노출 시켜 성장 속도를 빠르게 한 다음, 스트레스 호르몬 인 코티솔과 카테콜아민이 열충격 단백질로 이루어진 혈 액, 뇌 그리고 간의 조직에서 증가함을 보고하였고, Monaghan et al. (2009)는 빠른 성장이 산화 스트레스를 증가 시키는 요인임을 보고하였다. 산화 스트레스는 체내 에서 높아진 산화력에 의한 스트레스로서 활성산소의 파 괴로 세포내의 유전자 성분이나 근육을 위한 단백질 그리 고 세포막을 위한 지방의 변화를 일으키거나 세포의 활성 을 떨어뜨려 세포의 기능을 정지시킬 수 있다(Sies 2000). Nesa and Hidaka (2008)는 리프산호(Pavona divaricate) 의 서식지의 수온이 평균 $\left(25^{\circ} \mathrm{C}\right)$ 보다 높아 $\left(31^{\circ} \mathrm{C}\right)$ 졌을 때, 산화 스트레스가 증가하여 세포의 분열과 성장을 억제하 고 DNA를 손상시켰음을 확인하였고, 기후온난화에 의한 수온 상승이 산화 스트레스의 상승을 유도해 세포내 성장 을 방해하고 나아가 산호 군집의 규모가 감소할 수 있음 을 고찰하였다. 특히 Pike et al. (2007) 는 어린 큰 가시고 기를 이용한 보상성장 실험에서 빠른 성장속도에 따른 산 화 스트레스 양의 증가가 수컷 큰 가시고기의 붉은 혼인 색의 색상과 밝기를 탁하고 어둡게 하여 번식 기회가 감 소됨을 보였다. 이처럼 기후변화에 의한 온도 상승은 직간 접적으로 스트레스의 증가를 유도하고, 높아진 스트레스 는 성장과 번식 그리고 행동에 부정적인 영향을 주어 장 기적으로 생물다양성을 감소시키게 될 것이다.

과거 기후변화의 양상을 보면, 온도 변화의 차이는 크 지 않았지만 왜 생물에 미치는 영향은 급격히 증가 또는 감소하는 것일까(Parmesan and Yohe 2003; Karl et al. 2009)? 또한 앞으로의 기후변화 예측결과를 보면, 온도 상 승의 폭은 크지 않지만, 왜 생물은 민감하게 반응할 것이 라 예측하고 있는 것일까(Clark et al. 2012; Urban et al. 2012)? 하나의 가능한 이유로 앞서 언급한 스트레스 요인 간의 상호촉진관계 때문일 것이다. 즉, 산화스트레스는 기 후변화와 같은 하나의 요인에 의해 증가되기도 하지만, 또 
다른 스트레스 요소(예, 신진대사량)에 의하여 촉진될 수 있기 때문이다. 예를 들어, 냉혈동물에게 온도 상승은 신 진대사량를 높이고 성장 속도를 빠르게 하여 산화 스트레 스와 세포 손상을 증가시킨다. 더욱이 산화 스트레스는 신 진대사량에 의해 더 빠른 속도로 증가되므로(Harman 1956), 전체적인 스트레스 양은 지수함수의 형태로 증가한 다. 또한 성장을 빠르게 하기 위해서는 포식 빈도와 포식 시간이 늘어나야 하고, 이것은 포식될 위험과 먹이 경쟁을 증가시켜 결과적으로 코스티코스테론의 상승을 유도한다.

기후변화에 의한 스트레스의 증가는 개체군이나 군집의 개체 수 통계에도 영향을 주어 생물다양성의 구조를 변화 시킬 수 있다. 개체군이나 군집의 개체 수 통계는 생물의 이동뿐 만 아니라, 출생률과 사망률, 다시 말해 개체의 번 식성공과 수명에 의해 영향을 받는다. 최근 OzsarlakSozer et al. (2011)와 Shlush et al. (2011)는 산화 스트레 스의 증가는 텔로미어 길이를 빠르게 단축시킴으로써 수 명이 짧아짐을 보였다. 그리고 Heidinger et al. (2012)는 어린 금화조(Taeniopygia guttata)의 텔로미어 길이는 포 란 기간 동안 어미의 건강 상태가 나쁘고 부화 후에도 성 장 속도가 빨랐을 때에 빠르게 줄어들었고, 결과적으로 수 명이 감소하였음을 보였다. 결국 성장 속도와 스트레스 누 적 속도가 기후변화를 포함한 환경변화의 영향을 받아 생 활사 결과, 특히 번식과 수명에 영향을 주었을 것으로 사 료된다. 따라서 기후변화에 의한 작은 온도 변화도 다양한 종류의 스트레스 증가를 유도하고, 각각의 스트레스는 서 로 영향을 주어, 결과적으로 전체적인 스트레스 누적을 가 속시켜 개체의 적응도의 감소를 야기하고, 결과적으로 생 물다양성의 축소를 초래할 것으로 판단된다. 다시 말해, 스트레스에 따른 개체의 번식률 감소와 노화속도의 증가 는 개체군에서의 출생률 감소와 사망률 증가를 유도하여, 결국 생물다양성을 감소시키는데 직·간접적인 영향을 줄 수 있다. 이것은 왜 기후변화가 시·공간적으로 작은 온도 변화임에도 불구하고 생태적으로 큰 위협이 될 수 있을지 를 설명해준다. 하지만 아직 이러한 스트레스들 간의 상호 영향과 스트레스에 의한 생물다양성 구조 반응에 대해서 는 추가 실험연구가 시행되어야 한다.

\section{6. 향후 연구방향}

기후변화와 생태계, 특히 생물다양성과의 관계에 대한 연구는 지금까지 많은 연구가 진행되어 왔음에도 불구하 고 아직 많은 의문이 남아 있다. 더욱이 기후변화 시나리 오를 이용한 생물다양성의 변화 경향에 대한 예측은 그 결과의 정밀도를 높이기 위한 기술-이론적인 방법 연구 가 활발히 진행되고 있다. 예를 들어, 기후변화를 보다 정 밀하게 분석하기 위해, 수학적으로 다양한 '규모축소법
(Down-Scaling Method, DSM)'이 개발되고 있다(Maurer and Hidalgo 2008). 과거(혹은 현재 일부지역)에 수집된 기후 자료는 넓은 지역을 기준으로 하였기 때문에, 지역 군집 같이 좁은 지역 내에서의 기후변화 영향 예측에는 오류가 발생할 수 있고, 또한 예측에 대한 정밀도가 낮아 정확한 분석이 어렵다(Maurer and Hidalgo 2008). 따라서 규모축소법과 같이 넓은 지역의 정보를 작은 지역 단위로 변환하여 예측의 정확성을 높이기 위한 방법을 연구하고 있다. 마찬가지로 생물요인에 있어서도 다양성을 평가하 기 위해 군집이나 개체군 단위에서의 분산 형태나 구조의 분석이 많이 진행되어 왔지만, 최근에는 개체 하나 하나의 전략적 선택을 통한 생활사에서의 생리생태(번식, 이동, 수명) 변화를 바탕으로 예측하려는 노력이 시도되고 있다 (예, Baselga and Araujo 2009).

생물이 주어진 환경에서 적응하고 살아남기 위한 최적 의 선택은 생물의 생활사에 지속적인 영향을 준다. 보상성 장 기작에서 보았듯이 어린 시기에 짧은 시간동안 환경 변화에 노출된 개체는 전략적 선택으로써 성장과 번식에 대한 자원 분배 전략을 변경한다. 따라서 번식과 수명의 결과만을 놓고 기후변화의 영향을 평가하는 것보다, 기후 변화에 의한 개체의 생활사 전략과 그에 따른 결과를 분 석에 포함하는 것이 분석의 정밀도를 높일 수 있을 것이 다. 특히, 갑작스런 기후변화의 영향은 최종적인 생태적 결과를 통해서는 확인하기 어렵지만, 개체의 전략적 선택 에 따른 반응과 그에 따른 변경된 전략을 통해 파악이 가 능하다. 예를 들어, 기후변화의 영향으로 먹이 자원이 풍 부해지는 시기가 변하면, 새끼의 수, 즉 번식 성공률의 감 소로 이어지며, 장기적으로 개체군 감소와 번식서식지의 변경으로 이어질 수 있다. 따라서 향후 기후변화와 생물다 양성의 연구는 개체군이나 군집뿐 만 아니라 개체의 생활 사를 포함하는 접근법이 시도 되어야 할 것으로 사료된다.

\section{7. 결 론}

본 종설은 기후변화와 생물다양성과의 관계에 대한 연 구에 있어서 개체수준에서의 접근 필요성을 고찰하였다. 군집이나 개체군 수준에서의 기후변화의 영향에 대한 연 구는 1991년부터 꾸준히 증가추세를 보이고 있음에도 불 구하고, 최근 보고에 의하면 분석과 예측의 신뢰가 낮아지 고 있으며, 특히 일부 생태학자들은 온도 상승의 차이가 생물의 적응 과정을 방해할 만큼 크지 않기 때문에, 기후 변화의 영향은 예상보다 심각하지 않을 수도 있다고 주장 한다. 하지만, 환경에 대한 생물의 적응 전략으로 알려진 보상성장 기작은 온도 변화에 따른 생리적 변화와 신진대 사량의 증감 그리고 스트레스 누적 속도가 개체의 번식과 수명에 영향을 줄 수 있음을 보여준다. 이에 기후변화와 
보상성장 그리고 스트레스의 상호관계를 통해 작은 온도 변화에도 민감한 개체의 생태적 과정이 생물다양성에 영 향을 줄 수 있음을 제시하였다. 따라서 분석과 예측의 신 뢰를 높이기 위한 새로운 방법으로 기후변화와 생물다양 성과의 관계를 좀 더 생태적인 측면에서 분석하고, 동시에 개체의 생태적 과정과 상충관계에 의한 최적 선택 전략을 포함한 분석은 개체군이나 군집 단위에서의 기후변화에 따른 다양성의 변화 경향을 이해하는데 필요할 것이다.

\section{사 사}

논문에 대해 많은 시간을 들여 심사와 의견을 주신 편 집위원와 익명의 심사위원께 진심으로 감사드립니다. 또 한 논문을 위한 조언을 아끼지 않으신 Professor Pedro Peres-Neto, 박영석 교수님 그리고 유승화, 홍미진님께 고 마움을 전합니다. 본 연구는 캐나다 정부 초청 장학 (Government of Canada Postdoc Research Fellowship) 연 구 프로그램의 일환으로 수행되었습니다.

\section{참고문헌}

Agapow PM, Bininda-Emonds ORP, Crandall KA, Gittleman JL, Mace GM, Marshall JC, Purvis A (2004) The impact of species concept on biodiversity studies. Q Rev Biol 79:161-179

Ali M, Nicieza A, Wootton RJ (2003) Compensatory growth in fishes: a response to growth depression. Fish Fish 4:147-190

Álvarez D, Metcalfe NB (2005) Catch-up growth and swimming performance in threespine sticklebacks (Gasterosteus aculeatus): seasonal changes in the cost of compensation. Can J Fish Aquat Sci 62:2169-2176

Angelier F, Shaffer SA, Weimerskirch H, Trouve C, Chastel $\mathrm{O}$ (2007) Corticosterone and foraging behavior in a pelagic seabird. Physiol Biochem Zool 80:283-292

Arbuthnott D, Brigham RM (2007) The influence of a local temperature inversion on the foraging behaviour of big brown bats, Eptesicus fuscus. Acta Chiropterol 9:193-201

Baselga A, Araujo MB (2009) Individualistic vs community modelling of species distributions under climate change. Ecography 32:55-65

Bell MA, Foster SA (1994) The evolutionary biology of the threespine stickleback. Oxford University Press, Oxford, $584 \mathrm{p}$

Biro PA, Post JR, Booth DJ (2007) Mechanisms for climateinduced mortality of fish populations in whole-lake experiments. Proc Natl Acad Sci 104:9715-9719
Bone Q, Moore RH (2008) Biology of fishes. Taylor and Francls Group, New York, 478 p

Charnov EL (1997) Trade-off-invariant rules for evolutionary stable life histories. Nature 387:393-394

Clark CW, Butler RW (1999) Fitness components of avian migration: A dynamic model of Western Sandpiper migration. Evol Ecol Res 1:443-457

Clark JS, Bell DM, Kwit M, Stine A, Vierra B, Zhu K (2012) Individual-scale inference to anticipate climatechange vulnerability of biodiversity. Phil Trans R Soc B 367:236-246

Clinchy M, Zanette L, Charlier TD, Newman AEM, Schmidt KL, Boonstra R, Soma KK (2011) Multiple measures elucidate glucocorticoid responses to environmental variation in predation threat. Oecologia 166:607614

Costantini D, Metcalfe NB, Monaghan P (2010) Ecological processes in a hormetic framework. Ecol Lett 13:14351447

Cote IM, Hunte W (1989) Male and female mate choice in the redlip blenny - why bigger is better. Anim Behav 38:78-88

De Block M, Stoks R (2008) Compensatory growth and oxidative stress in a damselfly. Proc R Soc B 275:781785

Dickey MH, Gauthier G, Cadieux MC (2008) Climatic effects on the breeding phenology and reproductive success of an arctic-nesting goose species. Global Change Biol 14:1973-1985

Dmitriew CM (2011) The evolution of growth trajectories: what limits growth rate? Biol Rev 86:97-116

Ferguson M, Rebrin I, Forster MJ, Sohal RS (2008) Comparison of metabolic rate and oxidative stress between two different strains of mice with varying response to caloric restriction. Exp Gerontol 43:757-763

Fleming RA, Candau JN (1998) Influences of climatic change on some ecological processes of an insect outbreak system in Canada's boreal forests and the implications for biodiversity. Environ Monit Assess 49:235-249

Floder S, Jaschinski S, Wells G, Burns CW (2010) Dominance and compensatory growth in phytoplankton communities under salinity stress. J Exp Mar Biol Ecol 395:223-231

Frisard MI, Broussard A, Davies SS, Roberts LJ, Rood J, de Jonge L, Fang XB, Jazwinski SM, Deutsch WA, Ravussin E, Study LHA (2007) Aging, resting metabolic rate, and oxidative damage: results from the Louisiana healthy aging study. J Gerontol 62:752-759 
Garratt M, Vasilaki A, Stockley P, McArdle F, Jackson M,Hurst JL (2011) Is oxidative stress a physiological cost of reproduction? An experimental test in house mice. Proc R Soc B 278:1098-1106

Geiger S, M LEV, Lebard T, Reichert S, Stier A, Y LEM, Criscuolo F (2012) Catching-up but telomere loss: halfopening the black box of growth and ageing trade-off in wild king penguin chicks. Mol Ecol 21:1500-1510

Grimm V, Railsback SF (2005) Individual-based modelling and ecology. Princeton University Press, New York, $480 \mathrm{p}$

Groot C, Margolis L (1991) Pacific salmon life histories. University of British Columbia Press, Vancouver, Canada, $564 \mathrm{p}$

Harman D (1956) Aging: a theory based on free radical and radiation chemistry. J Gerontol 11:298-300

Haussmann MF, Mauck RA (2008) Telomeres and longevity: testing an evolutionary hypothesis. Mol Biol Evol 25:220-228

Heidinger BJ, Blount JD, Boner W, Griffiths K, Metcalfe NB, Monaghan P (2012) Telomere length in early life predicts lifespan. Proc Natl Acad Sci 109:1743-1748

Heidkamp E (2010) The recurring dark ages: ecological stress, climate change, and system transformation. Environ Hist 15:336-338

Hillebrand H, Matthiessen B (2009) Biodiversity in a complex world: consolidation and progress in functional biodiversity research. Ecol Lett 12:1405-1419

Inness CL, Metcalfe NB (2008) The impact of dietary restriction, intermittent feeding and compensatory growth on reproductive investment and lifespan in a short-lived fish. Proc R Soc B 275:1703-1708

Kalkstein LS (1993) Health and climate change. Direct impacts in cities. Lancet 342:1397-1399

Karl TR, Melillo JM, Peterson TC (2009) Global climate change impacts in the United States. Cambridge University Press, New York, $188 \mathrm{p}$

Kitano J, Ross JA, Mori S, Kume M, Jones FC, Chan YF, Absher DM, Grimwood J, Schmutz J, Myers RM, Kingsley DM, Peichel CL (2009) A role for a neo-sex chromosome in stickleback speciation. Nature 461:10791083

Lalouette L, Williams CM, Hervant F, Sinclair BJ, Renault D (2011) Metabolic rate and oxidative stress in insects exposed to low temperature thermal fluctuations. Comp Biochem Phys A 158:229-234

Le Lann C, Wardziak T, van Baaren J, van Alphen JJM (2011) Thermal plasticity of metabolic rates linked to life-history traits and foraging behaviour in a parasitic wasp. Funct Ecol 25:641-651

LeBlanc S, Middleton S, Gilmour KM, Currie S (2011) Chronic social stress impairs thermal tolerance in the rainbow trout (Oncorhynchus mykiss). J Exp Biol 214:1721-1731

Lee W-S, Monaghan P, Metcalfe NB (2012) The pattern of early growth trajectories affects adult breeding performance. Ecology 93:902-912

Lee W-S, Metcalfe NB, Monaghan P, Mangel M (2011) A comparison of dynamic-state-dependent models of the trade-off between growth, damage, and reproduction. Am Nat 178:774-786

Lee W-S, Monaghan P, Metcalfe NB (2010) The trade-off between growth rate and locomotor performance varies with perceived time until breeding. J Exp Biol 213:32893298

Leinonen T, Herczeg G, Cano JM, Merila J (2011) Predationimposed selection on threespine stickleback (Gasterosteus Aculeatus) morphology: a test of the refuge use hypothesis. Evolution 65:2916-2926

Love OP, Gilchrist HG, Descamps S, Semeniuk CAD, Bety J (2010) Pre-laying climatic cues can time reproduction to optimally match offspring hatching and ice conditions in an Arctic marine bird. Oecologia 164:277-286

Mangel M, Munch SB (2005) A life-history perspective on short- and long-term consequences of compensatory growth. Am Nat 166:E155-176

Marchinko KB, Schluter D (2007) Parallel evolution by correlated response: lateral plate reduction in threespine stickleback. Evolution 61:1084-1090

Marschall EA, Mather ME, Parrish DL, Allison GW, McMenemy JR (2011) Migration delays caused by anthropogenic barriers: modelling dams, temperature, and success of migrating salmon smolts. Ecol Appl 21: 3014-3031

Maurer EP, Hidalgo HG (2008) Utility of daily vs. monthly large-scale climate data: an intercomparison of two statistical downscaling methods. Hydrol Earth Syst Sc 12:551-563

Metcalfe NB, Alonso-Alvarez C (2010) Oxidative stress as a life-history constraint: the role of reactive oxygen species in shaping phenotypes from conception to death. Funct Ecol 24:984-996

Metcalfe NB, Monaghan P (2001) Compensation for a bad start: grow now, pay later? Trends Ecol Evol 16:254-260

Metcalfe NB, Monaghan P (2003) Growth versus lifespan: perspectives from evolutionary ecology. Exp Gerontol 38:935-940

Monaghan P, Metcalfe NB, Torres R (2009) Oxidative stress 
as a mediator of life history trade-offs: mechanisms, measurements and interpretation. Ecol Lett 12:75-92

Nesa B, Hidaka M (2008) Thermal stress increases oxidative NDA damage in coral cell aggregates. The 11th International Coral Reef Symposium, Florida, 7-11 July 2008

Nicieza AG, Metcalfe NB (1997) Growth compensation in juvenile Atlantic salmon: responses to depressed temperature and food availability. Ecology 78:2385-2400

Niehaus AC, Wilson RS, Seebacher F, Franklin CE (2011) Striped marsh frog (Limnodynastes peronii) tadpoles do not acclimate metabolic performance to thermal variability. J Exp Biol 214:1965-1970

O'Neill GA, Hamann A, Wang TL (2008) Accounting for population variation improves estimates of the impact of climate change on species' growth and distribution. J Appl Ecol 45:1040-1049

Ozsarlak-Sozer G, Kerry Z, Gokce G, Oran I, Topcu Z (2011) Oxidative stress in relation to telomere length maintenance in vascular smooth muscle cells following balloon angioplasty. J Physiol Biochem 67:35-42

Parmesan C (2006) Ecological and evolutionary responses to recent climate change. Annu Rev Ecol Evol S 37:637669

Parmesan C, Yohe G (2003) A globally coherent fingerprint of climate change impacts across natural systems. Nature 421:37-42

Pigliucci M (2001) Phenotypic plasticity: beyond nature and nurture. Johns Hopkins University Press, New York, $344 \mathrm{p}$

Pike TW, Blount JD, Lindstrom J, Metcalfe NB (2007) Availability of non-carotenoid antioxidants affects the expression of a carotenoid-based sexual ornament. Biol Lett 3:353-356

Reznick D, Nunney L, Tessier A (2000) Big houses, big cars, superfleas and the costs of reproduction. Trends Ecol Evol 15:421-425.

Rodl T, Berger S, Romero LM, Wikelski M (2007) Tameness and stress physiology in a predator-naive island species confronted with novel predation threat. Proc R Soc B 274:577-582

Rodway MS, Regehr HM (1999) Habitat selection and reproductive performance of food-stressed herring gulls. Conor 101:566-576

Roff DA (2002) Life history evolution. Sinauer, New York, $465 \mathrm{p}$
Sala OE, Chapin III FS, Gardner RH, Lauenroth WK, Mooney HA, Ramakrishnan PS (1999) Global change, biodiveristy and ecological complexity. In: Walker B, Steffen W, Canadell J, Ingram J (eds) The terrestrial biosphere and global change - implications for natural and managed ecosystems. Cambridge University Press, Cambridge, UK, pp 304-328

Schlichting CD, Pigliucci M (1998) Phenotypic evolution: a reaction norm perspective. Sinauer Assoiciate, Inc., New York, $340 \mathrm{p}$

Shlush LI, Skorecki KL, Itzkovitz S, Yehezkel S, Segev Y, Shachar H, Berkovitz R, Adir Y, Vulto I, Lansdorp PM, Selig S (2011) Telomere elongation followed by telomere length reduction, in leukocytes from divers exposed to intense oxidative stress--implications for tissue and organismal aging. Mech Ageing Dev 132:123-130

Sies H (2000) What is oxidative stress? In: Heaney JJF (ed) Oxidative stress and vascular disease. Kluwer Academic Publishers, New York, pp 1-8

Stearns SC (1989) Trade-offs in life-history evolution. Funct Ecol 3:259-268

Stott PA, Sutton RT, Smith DM (2008) Detection and attribution of Atlantic salinity changes. Geophys Res Lett 35:L21702

Tomita N, Niizuma Y, Takagi M, Ito M, Watanuki Y (2009) Effect of interannual variations in sea-surface temperature on egg-laying parameters of black-tailed gulls (Larus crassirostris) at Teuri Island, Japan. Ecol Res 24:157-162

Urban MC, Tewksbury JJ, Sheldon KS (2012) On a collision course: competition and dispersal differences create no-analogue communities and cause extinctions during climate change. Proc R Soc B. doi:10.1098/ rspb.2011.2367

Walther GR, Post E, Convey P, Menzel A, Parmesan C, Beebee TJC, Fromentin JM, Hoegh-Guldberg O, Bairlein F (2002) Ecological responses to recent climate change. Nature 416:389-395

Westerling AL, Bryant BP, Preisler HK, Holmes TP, Hidalgo HG, Das T, Shrestha SR (2011) Climate change and growth scenarios for California wildfire. Climatic Change 109:445-463

Received Mar. 19, 2012

Revised Jul. 3, 2012

Accepted Jul. 6, 2012 


\section{Appendix 1. The concept of compensatory growth and 'negative' compensatory growth}

Fig. A1a은 온도 처리에 따른 보상성장(이중점선)와 역 보상성장(점선), 그리고 온도가 일정하게 유지되었을 때의 안정된 성장 곡선(실선)을 보여준다. 시간 $t_{0}$ 에서 $t_{D}$ 동안 저온(이중점선)과 고온 처리(점선, 임계온도 보다는 낮은) 를 하면, 시간 $t_{D}$ 에서의 크기 또는 무게는 $m_{H}>m_{I}>m_{L}$ 로 유의한 차이가 생기며, 이후 온도를 동일하게 처리(이중점 선 - 온도 높임, 점선 - 온도 낮춤)하면, $t_{C}$ 에서의 크기 또는 무게는 모두 $m_{C}$ 로 차이가 없어진다. 성장속도는 보상 기 간 동안 $\left(=\right.$ 시간 $t_{P}$ 에서 $t_{C}$ 까지) 서로 다른 경향을 보였는 데, 각각 빠른 성장(이중점선), 느린 성장(점선) 그리고 안 정 성장(실선)이다. 전형적인 보상성장은 ‘catch-up' 성장 곡선의 형태를, 비전형적인 역보상성장은 'slow-down'의 형태를 보였다. 서로 다른 성장 곡선은 운동 능력과 번식 과정에 있어서도 각각 음(catch-up) 그리고 양(slow-down) 의 방향으로 영향을 주었다(Lee et al. 2010, 2012). 뿐만 아니라, 수명도 비슷한 방향으로 영향을 주었다(Lee et al. unpublished data, Fig. A1b): 역보상성장에서의 수명 $\left(=t_{H}\right)$ 은 안정된 성장보다 늘어났지만(점선), 보상성장에서의 수 명 $\left(=t_{L}\right)$ 은 감소하였다(이중점선).
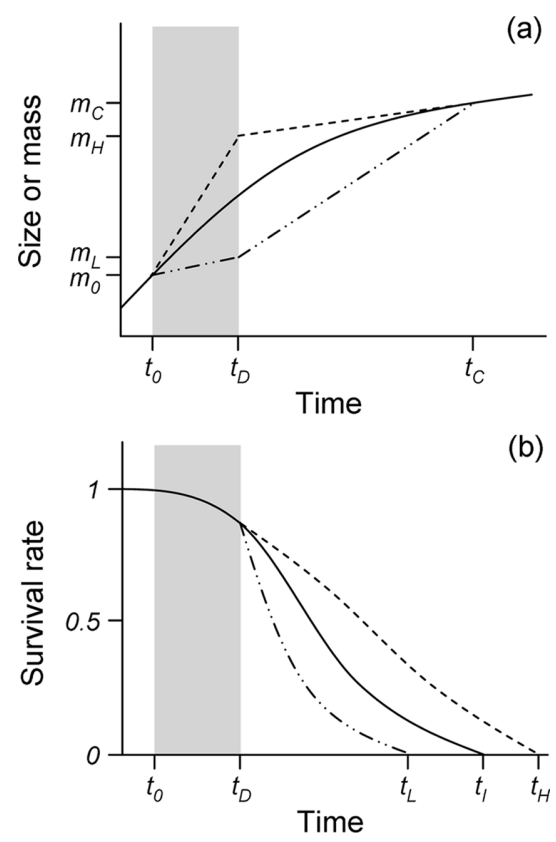

Fig. A1. (a) Growth trajectories induced by temperature manipulation during early in life: compensatory growth ('catch-up' trajectory, double-dotted line), 'negative' compensatory growth ('slow-down' trajectory, dashed line) and steady growth (solid line). (b) Survival rate trajectory among three growth trajectories (Lee et al. unpublished data)

\section{Appendix 2. 전문용어의 설명}

보상성장(compensatory growth) - 초기 발달 단계의 개체 는 극한 환경(먹이 제한, 수온 변동)하에서 성장이 멈추 거나 느려지게 되지만, 이러한 상황이 정상으로 회복되 면 성장은 훨씬 더 가속되어 정상 환경 하에서 성장한 개체들의 크기(또는 무게)와 곧 같아지게 되는데, 이러 한 기작을 보상성장(또는 catch-up 성장)이라고 함

상충 (또는 절충)관계(life history trade-off) - 일반적으로 어떤 두개 이상의 선택을 해야할 때 각각의 장단점을 고려하여 어느 하나를 버리고 더 나은 나머지를 선택하 는 상황을 설명함. 예를 들어, 어류가 취식 행동에 있어 서 넓은 취식 범위는 많은 먹이를 얻을 수 있지만, 반 대로 포식자에 의해 포식당할 확률이 높아진다. 따라서 포식위험은 낮추면서 동시에 많은 먹이를 먹을 수 있는 취식행동을 어류는 선택할 것이다. 이러한 선택의 과정 을 상충 (또는 절충)관계라고 함

섭식압(grazing pressure) - 생태계 먹이사슬 상에서 대상 종보다 하위단계에 있는 종을 섭식할 수 있는 정도

생태적 결과(ecological consequence) - 번식 뿐만 아니 라, 생물집단에서 나타나는 다양한 생태적 결론, 예를 들어, 성장, 운동성, 수명 등을 의미

생태적 적응도(ecological fitness) 또는 다윈적응도 (darwinian fitness) - 생물집단에서 특정한 독립적인 유 전형질을 가진 이전 세대의 개체수에 대한 다음 세대의 개체 수를 비율로 나타낸 것으로 일반적으로 한 개체에 서 생산되는 새끼의 수

생활사 결과(life history consequence) - 몸의 크기, 혼인 색, 번식성공률 등 생활사 요소들의 결과를 통칭하는 용어

생활사적 특징(life history traits) - 개체의 적응도에 직접 적으로 영향을 주는 특징을 의미하며, 번식(다산능력, 첫 번식때의 나이, 번식 가능 나이) 가능 시기나 번식결 과의 양과 관련되는 특징으로 설명

열충격 단백질(heat shock proteins, HSP) - 열에 약한 단백질이 외부로부터 열을 받았을 때, 몸이 스스로를 보호하기 위해 분비하는 단백질을 말하며, 열충격 단 백질은 열을 흡수함으로써 다른 세포가 변성되어 사 멸하는 것을 방지

포식압(predation pressure) - 생태계 먹이사슬 상에서 대 상종보다 상위 단계에 있는 종에 의해 포식당할 수 있 는 정도

형태적 유연성(phenotypic plasticity) - 생물체가 성장과정 동안 환경적 변화에 적응하기 위해 자신의 몸과 다른 특성들을 변화시킬 유연성을 갖추었다는 이론 